\title{
Pengaruh Gaya Kepemimpinan Participative Terhadap Prestasi Kerja Dan Kinerja Karyawan pada PT Hero Supermarket Tbk. Bintaro Divisi Sales Support
}

\author{
Inge Pratiwi, P. Helen Widjaja, Christina Catur Widayati \\ Fakultas Ekonomi dan Bisnis Universitas Mercu Buana, Fakultas Ekonomi \\ Universitas Tarumanagara \\ Email: christinewijaya73@yahoo.co.id dan
}

\begin{abstract}
This study aims to examine and analyze the influence of participative leadership style on employee performance dan performance. Research method used in this research is descriptive method. This research object is employee sales support division of PT Hero Supermarket Tbk. Bintaro with a population of 70 people. The sampling technique used a saturated sample with a sample size of 70 people. The approach used in this research is structural equation model (SEM) with Smart-PLS analysis. The result of this study show participative leadership style has a positive and significant impact on work performance. Participative leadership style has a positive and significant impact on employee performance.
\end{abstract}

Keywords: Participative Leadership Style, Work Performance, Employee Performance.

\begin{abstract}
Abstrak: Penelitian ini bertujuan untuk menguji dan menganalisis pengaruh gaya kepemimpinan partisipatif terhadap prestasi kerja dan kinerja karyawan. Metode penelitian yang digunakan dalam penelitian ini adalah metode deskriptif. Objek penelitian ini adalah karyawan divisi dukungan penjualan PT Hero Supermarket Tbk. Bintaro dengan populasi yaitu 70 orang. Teknik pengambilan sampel menggunakan sampel jenuh dengan jumlah sampel 70 orang. Pendekatan yang digunakan dalam penelitian ini adalah Structural Equation Model (SEM) dengan analisis Smart -PLS. Hasil penelitian ini menunjukkan gaya kepemimpinan partisipatif berpengaruh positif dan signifikan terhadap prestasi kerja. Gaya kepemimpinan partisipatif berpengaruh positif dan signifikan terhadap kinerja karyawan.
\end{abstract}

Kata Kunci: Gaya Kepemimpinan Participative, Prestasi Kerja, Kinerja Karyawan

\section{PENDAHULUAN}

Dalam peradaban manusia sekarang ini segala aspek kehidupan tidak lepas dari berorganisasi, karena pada kodratnya manusia merupakan makhluk sosial yang cenderung untuk selalu hidup bermasyarakat. Hal ini nampak didalam kehidupan rumah tangga, organisasi kemasyarakatan, terlebih pada saat seseorang memasuki dunia kerja (Robbins, 2006). Seseorang tersebut akan berinteraksi, dan masuk menjadi bagian dalam organisasi tempatnya bekerja. Organisasi adalah unit sosial yang dengan sengaja dikelola, terdiri atas dua orang atau lebih, yang berfungsi secara relativeterus-menerus untuk mencapai satu sasaran atau serangkaian sasaran bersama. 
Dalam pencapaian tujuan banyak unsur-unsur yang menjadi hal penting dalam pemenuhannya, diantaranya adalah unsur kepemimpinan atau pemimpin. Dasarnya kepemimpinan merupakan gaya seorang pemimpin mempengaruhi bawahannya agar mau bekerja sama dan bekerja efektif oleh seorang pemimpin ini yang akan digunakan untuk dapat mengarahkan sumber daya manusia dapat menggunakan semua kemampuannya dalam mencapai kinerja yang baik.

Hutapea dan Nurianna (2008) mengemukakan bahwa peran sumber daya manusia perlu dikelola secara profesional. Peran sumber daya manusia yang semula hanya sebagai penunjang perlu diubah menjadi strategik, dimana pengelolaan sumber daya manusia ditujukan agar organisasi dapat beroperasi dengan efisien sehingga dapat mencapai sasaran kerjanya.

Menurut Sedarmayanti (2009) Gaya kepemimpinan merupakan tindakan pemimpin saat di dunia kerja dimana dia mempunyai bawahan. Baik buruknya tindakan pemimpin saat berada pada waktu kerja tersebut itu juga dinamakan gaya kepemimpinan. Menurut Sugandi (2011) gaya kepemimpinan participative merupakan gaya kepemimpinan yang memiliki karakteristik sebagai berikut, dalam proses pergerakan bawahan selalu bertitik tolak dari pendapat bahwa manusia itu adalah makhluk yang termulia di dunia, selalu berusaha mensinkronisasikan kepentingan dan tujuan organisasi dalam kepentingan dan tujuan pribadi dari para bawahannya, senang menerima saran, pendapat bahkan kritik dari bawahan selalu berusaha menjadikan bawahannya sukses dan berusaha mengembangkan kapasitas diri pribadi sebagai pemimpin.

Menurut Hasibuan (2008) prestasi kerja merupakan hasil kerja yang dicapai seseorang dalam melaksanakan tugas-tugas yang diberikan kepadanya yang didasarkan atas kecakapan dan kesungguhan serta waktu. Sedangkan menurut Mangkunegara (2009) prestasi kerja adalah hasil kerja secara kualitas dan kuantitas yang dicapai oleh seorang pegawai dalam melaksanakan tugasnya sesuai dengan tanggung jawab yang diberikan kepadanya.

Menurut Hasibuan (2012) kinerja adalah suatu hasil yang dicapai oleh seseorang dalam melaksanakan tugas-tugas yang dibebankan kepadanya. Sedangkan menurut Sedarmayanti (2011) kinerja merupakan terjemahan dari performance yang berarti hasil kerja seorang pekerja, sebuah proses manajemen atau suatu organisasi secara keseluruhan, dimana hasil kerja tersebut harus dapat ditunjukkan buktinya secara konkrit dan dapat diukur (dibandingkan dengan standar yang telah ditentukan).

Menurut Hendra (2007) setiap pemimpin selalu berusaha agar para karyawannya memiliki kinerja dan prestasi kerja yang optimal agar tujuan perusahaan yang telah ditetapkan tercapai, permasalahan yang terjadi pada kinerja dan prestasi kerja yang menurun diakibatkan kurangnya peranan pemimpin yang efektif.

Tabel 1. Hasil Data Pra Survey

\begin{tabular}{lllll}
\hline No. & \multicolumn{1}{c}{ Pernyataan } & $\begin{array}{c}\text { Total } \\
\text { Target }\end{array}$ & Ya & Tidak \\
\hline 1. & $\begin{array}{l}\text { Pimpinan di tempat saya bekerja selalu melibatkan } \\
\text { karyawan dalam penetapan suatu tujuan }\end{array}$ & $100 \%$ & $35 \%$ & $65 \%$ \\
2. $\begin{array}{l}\text { Pimpinan saya dalam membuat keputusan dibuat } \\
\text { bersama antara pimpinan dan karyawan }\end{array}$ & $100 \%$ & $40 \%$ & $60 \%$ \\
3. Pimpinan memberikan arahan berupa penjelasan & $100 \%$ & $30 \%$ & $70 \%$ \\
\hline
\end{tabular}


mengenai bagaimana melaksanakan pekerjaan dengan baik

4. Penilaian atas prestasi kerja yang dilaksanakan untuk saya sesuai dengan kenyataan yang terjadi

5. Saya bersedia bekerja tanpa harus diperintah atau diminta oleh pimpinan

6. Kualitas kerja saya memuaskan

7. Skill yang saya miliki sesuai dengan pekerjaan yang saya kerjakan

8. Saya dapat mengerjakan pekerjaan dengan efektif dan efisien sehingga tidak perlu banyak instruksi dan umpan balik dari pimpinan

9. Teknologi yang digunakan perusahaan sangat $100 \% \quad 80 \% \quad 20 \%$ membantu dalam meningkatkan kinerja karyawan

10. Saya dapat mencapai kualitas kerja yang maksimal $\quad 100 \% \quad 75 \% \quad 25 \%$ sesuai dengan fasilitas kerja yang saya miliki

Sumber: Data Pra Survey Pada PT Hero Supermarket Tbk. Bintaro Divisi Sales Support

Menurut hasil pra survey pada Tabel 1. dapat dilihat bahwa pada 10 karyawan yang telah mengisi kuesioner terdapat permasalahan yaitu karyawan memberikan respon negatif sebesar $70 \%$ pada pernyataan "Pimpinan memberikan arahan berupa penjelasan mengenai bagaimana melaksanakan pekerjaan dengan baik". Artinya pemimpin dalam memberikan arahan kepada karyawannya kurang efektif sehingga karyawan sering tidak memahami perintah yang diberikan oleh pimpinan.

Menurut Human Resources Development PT Hero Supermarket Tbk. Bintaro yang diwawancarai oleh peneliti mengungkapkan adanya penurunan prestasi dan kinerja karyawan yang berpengaruh terhadap tidak tercapainya tujuan yang telah ditetapkan oleh perusahaan. Salah satu indikasinya adalah tingkat absensi karyawan seperti ketidakhadiran seorang karyawan untuk bekerja sesuai dengan waktu yang sudah dijadwalkan maupun keterlambatan mengalami peningkatan yang tidak sesuai dengan prosedur yang ditetapkan oleh perusahaan.

Ini semua dapat menjadi indikasi bahwa perusahaan telah mengalami penurunan prestasi kerja dan kinerja karyawan. Hal ini disebabkan oleh gaya kepemimpinan yang telah ditetapkan didalam perusahaan yang diterima oleh karyawan. Apabila kondisi tersebut tidak segera diatasi akan menyebabkan tujuan yang ditetapkan perusahaan tidak tercapai dikarenakan pimpinan dalam mengarahkan tugas dan pekerjaan kurang efektif sehingga menurunkan prestasi dan kinerja karyawan. Fenomena ini diperkuat dengan adanya absensi karyawan pada bulan November 2015 sampai Mei 2016 dan hasil pengukuran kinerja karyawan PT Hero Supermarket Tbk. Bintaro pada divisi sales support pada tahun 2016. 


\section{Jumlah Ketidakhadiran Karyawan}

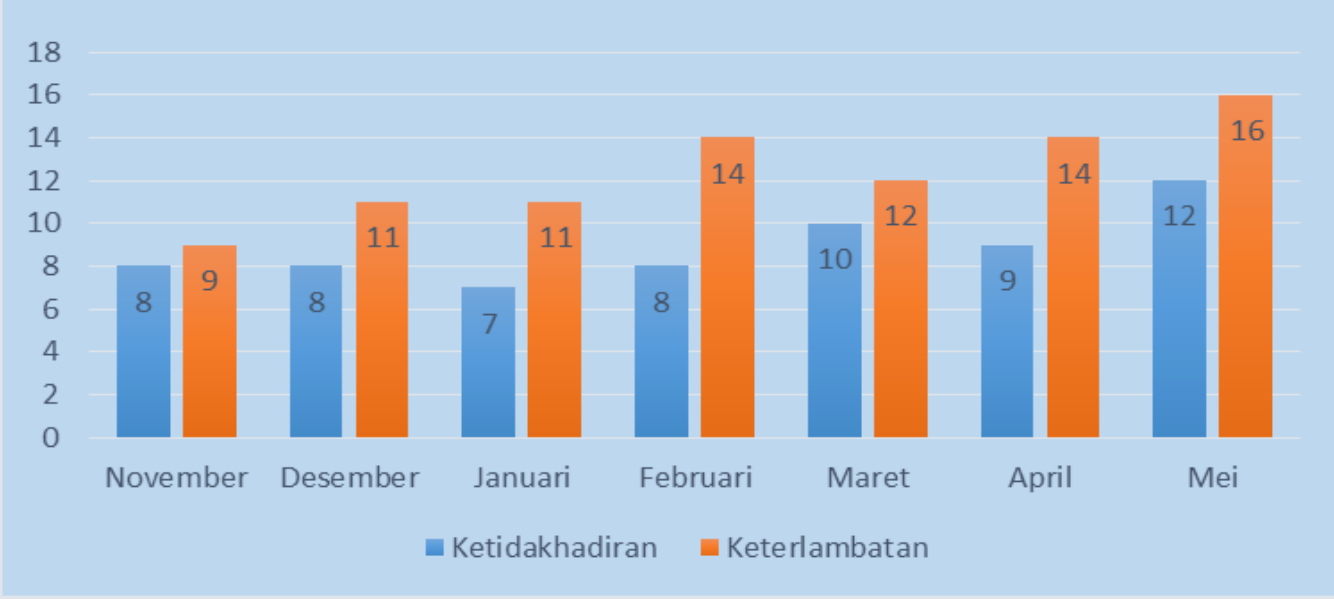

Grafik 1. Daftar Ketidakhadiran Karyawan pada PT Hero Supermarket Tbk. Bintaro Sumber: Biro Sumber Daya Manusia

Daftar Ketidakhadiran Karyawan pada PT Hero Supermarket Tbk. Bintaro Bulan November 2015 - Mei 2016. Terlihat dari Grafik 1. sebagai bukti ketidakhadiran karyawan paling tinggi dibulan Mei sebanyak 12 karyawan dan paling sedikit dibulan Januari sebanyak 7 karyawan. Tingkat keterlambatan karyawan paling tinggi dibulan Mei sebanyak 16 karyawan dan paling sedikit dibulan November sebanyak 9 karyawan. Oleh karena itu perusahaan menitikberatkan suatu tujuan dapat dicapai atau tidaknya pada karyawan. Dari data diatas dapat dilihat bahwa absensi karyawan masih belum optimal. Disinilah peran seorang pemimpin sangat diperlukan dalam meningkatkan prestasi dan kinerja karyawan, terutama dalam hal menyampaikan informasi atau perintah harus secara efektif dan dalam pemberian tugas atau pekerjaan harus lebih sesuai dengan prosedur yang berlaku.

Berdasarkan Tabel 1. hasil pengukuran kinerja karyawan pada PT Hero Supermarket Tbk. Bintaro divisi sales support dari empat unsur indikator pengukuran kinerja pada tahun 2016 dapat dilihat bahwa presentase untuk indikator "Peningkatan kualitas karyawan divisi sales support setelah mengikuti training" sebesar $92 \%$ dari target 95\%. Artinya karyawan yang telah melakukan training belum bisa mencapai target yang telah ditetapkan dikarenakan karyawan masih belum maksimal dalam mengimplementasikan apa yang sudah diterapkan pada saat training. Pada presentase indikator kedua yaitu "Peningkatan kualitas karyawan dalam melayani pelanggan" sebesar 93\% dari target 95\%. Artinya karyawan dalam melayani pelanggan kurang maksimal karena belum mencapai target yang ditentukan oleh perusahaan. Selanjutnya pada presentase indikator ketiga yaitu "Peningkatan kualitas karyawan dalam ketelitian, ketertiban, keramahan, dan inisiatif" sebesar 95\% dari target 95\%. Artinya karyawan cukup teliti, tertib, ramah dan juga berinisiatif didalam melaksanakan pekerjaannya, dan karyawan pun masih bisa terus meningkatkan hal tersebut agar bisa melebihi target yang diharapkan perusahaan sehingga dapat meningkatkan kinerja karyawan. Dan selanjutnya 
pada presentase indikator keempat yaitu "Kepuasan pelanggan terhadap pelayanan karyawan" sebesar 97\% dari target 95\%. Artinya pelanggan cukup puas terhadap pelayanan yang diberikan karyawan seperti keramahan karyawan terhadap pelanggan, teliti terhadap barang belanjaan yang dibeli oleh pelanggan sehingga jarang terjadi kesalahan yang dilakukan karyawan.

Berdasarkan uraian pada latar belakang masalah diatas, dapat di identifikasikan beberapa masalah, yaitu: (1) Apakah gaya kepemimpinan participative berpengaruh terhadap prestasi kerja karyawan di PT Hero Supermarket Tbk. Bintaro divisi sales support?; (2) Apakah gaya kepemimpinan participative berpengaruh terhadap kinerja kerja karyawan di PT Hero Supermarket Tbk. Bintaro divisi sales support?

Tujuan penelitian ini adalah sebagai berikut: (1) Untuk menganalisis dan mengetahui pengaruh gaya kepemimpinan participative terhadap prestasi kerja karyawan di PT Hero Supermarket Tbk. Bintaro divisi sales support; (2) Untuk menganalisis dan mengetahui pengaruh gaya kepemimpinan participative terhadap kinerja karyawan di PTHero Supermarket Tbk. Bintaro divisi sales support

\section{KAJIAN TEORI}

Pengertian Manajemen Sumber Daya Manusia. Sumber Daya Manusia yang professional adalah yang sangat dibutuhkan oleh setiap perusahaan guna menjalankan tugas-tugasnya demi mencapai tujuan yang diharapkan perusahaan tersebut. Salah satu hal yang menyebabkan pentingnya sumber daya manusia adalah bagaimanapun tingginya suatu teknologi dan berbagai sistem komputer yang dipergunakan dalam operasional proses pengolahan, namun faktor manusia tetap merupakan unsur penting dalam pengoperasian teknologi tersebut. Tidak ada satu pun dari teknik atau metode manajemen akan efektif tanpa ada unsur manusia yang mengatur, tanpa dilaksanakan tenaga kerja yang terampil.

Menurut Hasibuan (2006) Manajemen Sumber Daya Manusia merupakan ilmu dan seni mengatur hubungan dan peranan tenaga kerja agar efektif dan efisien membantu terwujudnya tujuan perusahaan, karyawan, dan masyarakat. Samsudin (2006) berpendapat bahwa Manajemen Sumber Daya Manusia terdiri dari serangkaian kebijakan yang terintegrasi tentang hubungan ketenagakerjaan yang mempengaruhi orang-orang dalam perusahaan, Manajemen Sumber Daya Manusia merupakan aktivitas-aktivitas yang dilaksanakan agar sumber daya manusia dalam perusahaan dapat didayagunakan secara efektif dan efisien guna mencapai berbagai tujuan.

Sedangkan menurut Bohlarander dan Snell (2010) Manajemen Sumber Daya Manusia merupakan ilmu yang mempelajari bagaimana memberdayakan karyawan dalam perusahaan, membuat pekerjaan, kelompok kerja, mengembangkan para karyawan yang mempunyai kemampuan, mengidentifikasi suatu pendekatan untuk dapat mengembangkan kinerja karyawan dan memberikan imbalan kepada mereka atas usahanya dan bekerja.

Peranan sumber daya manusia bagi kesuksesan suatu perusahaan sangatlah menentukan, kendatipun tidak dapat dipungkiri bahwa sekarang ini dunia berada pada era globalisasi yang serba modern. Tenaga manusia sudah banyak yang telah digantikan oleh peralatan yang serba canggih seperti: mesin-mesin otomatis, komputer dan lain-lain yang bergerak secara efektif dan efisien. 
Dari beberapa definisi diatas dapat disimpulkan manajemen sumber daya manusia ialah pemberdayaan sumber daya manusia dalam organisasi agar lebih efektif dan efisien untuk mencapai tujuan-tujuan organisasi, karyawan dan masyarakat.

Kepemimpinan. Hasibuan (2007) kepemimpinan adalah proses mempengaruhi orang lain untuk memahami dan setuju tentang apa yang akan dikerjakan dan bagaimana tugas itu dapat dilakukan secara efektif, dan proses memfasilitasi usaha individu dan kelompok untuk mencapai tujuan bersama. Menurut Ivancevich, et al (2007) kepemimpinan adalah sebagian proses mempengaruhi orang lain untuk mendukung pencapaian tujuan organisasi yang relevan. Daft (2009) berpendapat bahwa kepemimpinan berguna untuk memberikan motivasi kepada karyawan untuk mencapai tujuan organisasi. Sedangkan menurut Usman (2011) kepemimpinan adalah hubungan yang ada dalam diri seorang pemimpin, mempengaruhi orang lain untuk bekerja secara sadar dalam hubungan tugas yang diinginkan. Secara umum pengertian kepemimpinan adalah kemampuan yang dimiliki seseorang untuk mempengaruhi orang lain dalam upaya mencapai tujuan dan sasaran perusahaan.

Dari berbagai definisi diatas dapat disimpulkan bahwa kepemimpinan merupakan proses dari seorang pemimpin untuk mempengaruhi orang lain dan juga memberikan motivasi dalam bekerja untuk mencapai tujuan organisasi. Menurut Sunyoto (2015), sifatsifat yang harus dimiliki oleh seorang pemimpin adalah: (1) Kemampuan dalam kedudukannya sebagai pengawas atau melaksanakan fungsi-fungsi dasar manajemen, terutama pengarahan dan pengawasan pekerjaan orang lain; (2) Kebutuhan akan prestasi dalam pekerjaan, mencakup pencarian tanggung jawab dan keinginan sukses; (3) Kecerdasan, mencakup kebijakan, pemikiran kreatif dan daya pikir; (4) Ketegasan atau kemampuan untuk membuat keputusan-keputusan dan memecahkan masalah-masalah dengan cakap dan tepat; (5) Kepercayaan diri atau pandangan terhadap dirinya sebagai kemampuan untuk menghadapi masalah; (6) Inisiatif atau kemampuan untuk bertindak tidak bergantung, mengembangkan serangkaian kegiatan dan menemukan cara-cara baru atau inovasi.

Gaya Kepemimpinan. Gaya kepemimpinan pada dasarnya mengandung pengertian sebagai suatu perwujudan tingkah laku dari seorang pemimpin yang menyangkut kemampuannya dalam memimpin. Perwujudan tersebut biasanya membentuk suatu pola atau bentuk tertentu. Gaya kepemimpinan juga dapat dikatakan sebagai gaya yang dapat memaksimalkan produktivitas, kepuasan kerja, pertumbuhan, dan mudah menyesuaikan dengan segala situasi.

Menurut Herujito (2006) mengartikan bahwa gaya kepemimpinan bukan bakat, oleh karena itu gaya kepemimpinan dipelajari dan dipraktekan dalam penerapannya harus sesuai dengan situasi yang dihadapi. Menurut Supardi (2006) mengungkapkan bahwa gaya kepemimpinan adalah suatu cara dan proses kompleks dimana seseorang mempengaruhi orang-orang lain untuk mencapai suatu misi, tugas atau suatu sasaran dan mengarahkan organisasi dengan cara yang lebih masuk akal. Sedangkan menurut Thoha (2010) mengemukakan bahwa gaya kepemimpinan merupakan norma perilaku yang digunakan oleh seseorang pada saat orang tersebut mencoba mempengaruhi perilaku orang lain atau bawahan. Dan menurut Miftah (2007) gaya kepemimpinan adalah norma perilaku yang digunakan oleh seseorang pada saat orang tersebut mencoba 
mempengaruhi perilaku orang lain seperti yang ia lihat. Adapun jenis-jenis gaya kepemimpinan yang dibahas dalam penulisan ini adalah gaya kepemimpinan participative.

Gaya Kepemimpinan Participative. Menurut Thoha (2010) mengatakan bahwa gaya kepemimpinan participative dikaitkan dengan kekuatan personal dan keikutsertaan para pengikut dalam proses pemecahan masalah dan pengambilan keputusan. Burhanuddin (2014) kepemimpinan participativemerupakan salah satu gaya kepemimpinan yang dipakai oleh mereka yang dipercaya, yaitu dengan kepercayaan dan kredibilitasnya itu kemudian memotivasi orang-orang yang melibatkan mereka dalam proses pengambilan keputusan. Dengan demikian, kepemimpinan partisipatif adalah kepemimpinan yang memberikan ruang dan peran secara signifikan kepada bawahan dalam meningkatkan aktivitas pengambilan keputusan.

Gaya kepemimpinan ini menempatkan manusia sebagai faktor pendukung terpenting dalam kepemimpinan yang dilakukan berdasarkan dan mengutamakan orientasi pada hubungan dengan anggota organisasi. Gaya kepemimpinan participative ini cocok apabila tujuan perusahaan telah dikomunikasikan dan para bawahan telah menerimanya. Perusahaan menggunakan hadiah dan ketertiban sebagai alat motivasi utama, pimpinan benar-benar menginginkan untuk mendengarkan pendapat dan ide-ide dari para bawahan sebelum mengambil keputusan, dimana pimpinan menginginkan untuk mengembangkan kemampuan analitis dan self control dari para bawahannya. Para bawahan cukup berpengetahuan dan berpengalaman, para bawahan menginginkan ketertiban dalam mengambil keputusan dan waktu untuk menyelesaikan tugas memungkinkan untuk partisipasi.

Menurut Sudriamunawar (2006) Gaya kepemimpinan participative ini dikenal dengan istilah gaya demokratis, gaya ini berasumsi bahwa para anggota organisasi yang ambil bagian secara pribadi dalam proses pengambilan keputusan akan lebih memungkinkan sebagai suatu akibat mempunyai komitmen yang jauh lebih besar pada sasaran dan tujuan organisasi, bukan tidak berarti para pemimpin tidak membuat keputusan tetapi justru para pemimpin seharusnya memahami terlebih dahulu apakah yang menjadi sasaran organisasi sehingga mereka dapat menggunakan pengetahuan para anggotanya.

Dimensi dan Indikator Gaya Kepemimpinan Participative. Menurut Hasibuan (2007) Gaya Kepemimpinan Participative memiliki dimensi dan indikator sebagai berikut: (1) Wewenang pemimpin tidak mutlak/Bawahan harus berpartisipasi memberikan saran, ide, dan pertimbangan-pertimbangan dalam proses pengambilan keputusan; (2) Keputusan dan kebijakan dibuat bersama. Keputusan tetap dilakukan pimpinan dengan mempertimbangkan saran atau ide yang diberikan bawahannya.(3) Pengawasan terhadap tingkah laku. Pimpinan memperhatikan dalam bersikap dan bertindak, adanya saling percaya dan menghormati. (4) Keaktifan. Pimpinan melakukan komunikasi dua arah secara langsung dan juga memberi kesempatan kepada karyawan untuk memberi pertimbangan dalam pengambilan keputusan.

Berdasarkan faktor-faktor tersebut, maka jelaslah bahwa kesuksesan pemimpin dalam aktivitasnya dipengaruhi oleh faktor-faktor yang dapat menunjang untuk berhasilnya suatu kepemimpinan, oleh sebab itu suatu tujuan akan tercapai apabila terjadinya keharmonisan dalam hubungan atau interaksi yang baik antara atasan dan 
bawahan, disamping dipengaruhi oleh latar belakang yang dimiliki pemimpin, seperti motivasi diri untuk berprestasi, kedewasaan dan keleluasaan dalam hubungan sosial dengan sikap-sikap hubungan manusiawi.

Prestasi Kerja. Menurut Sutrisno (2011) Prestasi kerja adalah hasil upaya seseorang yang ditentukan oleh kemampuan karakteristik pribadinya serta persepsi terhadap perannya terhadap pekerjaan itu. Prestasi kerja adalah hasil yang dicapai atau diinginkan oleh semua orang dalam bekerja, prestasi kerja untuk tiap orang tidaklah sama ukurannya karena manusia itu satu sama lain berbeda, perbedaan ini terletak pada diri maupun luar individu. Prestasi juga merupakan hasil kerja seorang karyawan selama periode tertentu dibandingkan dengan berbagai kemungkinan misalnya target atau sasaran atau kriteria yang telah ditentukan terlebih dahulu dan disepakati bersama.

Menurut Mangkunegara (2009) Prestasi kerja adalah hasil kerja secara kualitas dan kuantitas yang dicapai oleh seseorang pegawai dalam melaksanakan tugasnya sesuai dengan tanggung jawab yang diberikan kepadanya. Dan menurut Handoko (2012) prestasi kerja sebagai ungkapan kemampuan yang didasari oleh pengetahuan, sikap, keterampilan dan motivasi dalam menghasilkan sesuatu.

Berdasarkan pendapat para ahli diatas mengenai prestasi kerja maka dapat disimpulkan bahwa prestasi merupakan hasil kerja yang dihasilkan oleh karyawan atau perilaku nyata yang ditampilkan sesuai dengan peranannya dalam organisasi. Penilaian prestasi kerja adalah proses penilaian prestasi kerja karyawan yang dilakukan oleh organisasi terhadap karyawannya secara sistematis dan formal berdasarkan pekerjaan yang ditugaskan kepadanya.

Dimensi dan Indikator Prestasi Kerja. Sutrisno (2010) mengatakan pengukuran prestasi kerja diarahkan pada enam aspek yang merupakan bidang prestasi kunci bagi organisasi, yaitu: (a) Hasil kerja. Tingkat kuantitas maupun kualitas yang telah dihasilkan dan sejauh mana pengawasan dilakukan; (b) Pengetahuan pekerjaan. Tingkat pengetahuan yang terkait dengan tugas pekerjaan yang akan berpengaruh langsung terhadap kuantitas dan kualitas dari hasil kerja; (c)Inisiatif. Tingkat inisiatif selama melaksanakan tugas pekerjaan khususnya dalam hal penanganan masalah-masalah yang timbul;(d) Kecekatan mental. Tingkat kemampuan dan kecepatan dalam menerima instruksi kerja, dan menyesuaikan dengan cara kerja serta situasi kerja yang ada; (e) Sikap.Tingkat semangat kerja serta sikap positif dalam melaksanakan tugas pekerjaan; (f) Disiplin waktu dan absensi. Tingkat ketepatan waktu dan tingkat kehadiran

Menurut Sutrisno (2010: 153) menyatakan bahwa indikator-indikator prestasi kerja yaitu: (1) Kualitas kerja (Quality) yaitu taraf kesempurnaan proses kerja atau pemenuhan aktivitas kerja yang ideal dan diharapkan; (2) Kuantitas kerja (Quantity) yaitu jumlah yang dihasilkan dalam konteks nilai uang, jumlah unit, atau jumlah penyelesaian suatu siklus aktivitas; (3) Jangka waktu (Timeliness) yaitu tingkat penyesuaian suatu aktivitas yang dikerjakan atau suatu hasil dicapai dengan waktu untuk aktivitas lainnya; (4) Efektifitas biaya (Cost Efectiveness) yaitu tingkat maksimalisasi sumber daya organisasi untuk memperoleh hasil terbanyak atau menekan kerugian. 
Kinerja Karyawan. Menurut Marwansyah (2014) kinerja adalah pencapaian atau prestasi seseorang berkenaan dengan tugas-tugas yang dibebankan kepadanya. Dan menurut Veithzal Rival Zainnal (2014) kinerja adalah tingkat pencapaian hasil atas pelaksanaan tugas tertentu.Sedangkan menurut Mathis dan Jackson (2006) menyatakan bahwa kinerja pada dasarnya adalah apa yang dilakukan atau tidak dilakukan pegawai.

Dimensi dan Indikator Kinerja. Sudarmanto (2009) mengemukakan empat dimensi yang dijadikan sebagai tolak ukur dalam menilai kinerja, yaitu: (1) Kualitas, yaitu tingkat kesalahan, kerusakan, kecermatan; (2) Kuantitas, yaitu jumlah pekerjaan yang diberikan; (3) Penggunaan waktu dalam bekerja, yaitu tingkat ketidakhadiran, keterlambatan waktu kerja efektif atau jam kerja hilang; (4) Kerja sama dengan orang lain dalam bekerja; (5) Kemandirian, suatu tingkat dimana karyawan mempunyai komitmen kerja dengan instansi dan tanggung jawab karyawan terhadap kantor.

Dari kelima dimensi kinerja diatas, dua hal terkait dengan aspek keluaran dan hasil pekerjaan, yaitu: kualitas hasil, kuantitas keluaran dan tiga hal yang terkait aspek perilaku individu, yaitu: penggunaan waktu dalam bekerja (tingkat kepatuhan terhadap jam kerja, disiplin), kerjasama dan kemandirian. Dari lima dimensi kinerja tersebut cenderung mengukur kinerja pada level individu.

Menurut Mangkunegara (2009) yang mengatakan bahwa kinerja (performance) dipengaruhi oleh tiga faktor atau dimensi, yaitu faktor/dimensi individual (atribut individu), faktor/dimensi psikologis (upaya kerja atau work effort) dan faktor/dimensi organisasi (dukungan organisasi). Dengan pendapat tersbeut, dirangkai suatu definisi konseptual variabel penelitian bahwa kinerja adalah sebagai hasil-hasil yang dicapai oleh individu dalam melaksanakan tugas yang telah diembankan kepadanya, baik dari segi kualitas maupun kuantitas berdasarkan standar kerja yang telah ditentukan, yang meliputi atribut individu, upaya kerja (work effort) dan dukungan organisasi.

Hubungan Antar Variabel. Pengaruh Gaya Kepemimpnan Participative Terhadap Prestasi Kerja. Pengaruh Gaya Kepemimpinan Participative Terhadap Prestasi Kerja. Untuk meningkatkan prestasi kerja karyawan, perusahaan atau organisasi diharapkan mampu untuk menyusun suatu skenario kepemimpinan yang layak bagi karyawan. Gaya Kepemimpinan Participative sangat dibutuhkan dalam mengarahkan karyawan untuk meningkatkan prestasi kerja karyawan. Prestasi kerja akan berdampak langsung dalam pencapaian tujuan perusahaan secara keseluruhan. Keberhasilan suatu perusahaan dalam mencapai tujuannya sangat ditentukan oleh gaya kepemimpinan yang terdapat dalam suatu perusahaan. Gaya kepemimpinan participative ini cocok apabila tujuan perusahaan telah dikomunikasikan dan para bawahan telah menerimanya. Perusahaan menggunakan hadiah dan ketertiban sebagai alat motivasi utama, pimpinan benar-benar menginginkan untuk mendengarkan pendapat dan ide-ide dari para bawahan sebelum mengambil keputusan, dimana pimpinan menginginkan untuk mengembangkan kemampuan analitis dan self control dari para bawahannya. Penelitian mengenai Pengaruh Gaya Kepemimpinan Participative terhadap Prestasi Kerja pernah dilakukan Djoko Soelistya (2014) yang menghasilkan gaya kepemimpinan participative berpengaruh positif dan signifkan terhadap kinerja karyawan.

H1: Gaya Kepemimpinan Participative berpengaruh positif dan signifikan terhadap prestasi kerja karyawan. 
Pengaruh Gaya Kepemimpinan Participative Terhadap Kinerja Karyawan. Di era globalisasi seperti sekarang ini salah satu permasalahan yang sangat krusial dalam mekanisme perusahaan adalah masalah kinerja karyawan. Posisi karyawan sebagai jantung sebuah perusahaan, di mana seluruh kegiatan karyawan dipandang sebagai faktor penentu bagi tercapainya tujuan perusahaan. Kepemimpinan yang efektif dapat menunjang peningkatan kinerja karyawan menuntut peran manajemen dalam melalui pendekatan kepemimpinan yang efektif. Salah satu gaya kepemimpinan participative. Gaya kepemimpinan ini menempatkan manusia sebagai faktor pendukung terpenting dalam kepemimpinan yang dilakukan berdasarkan dan mengutamakan orientasi pada hubungan dengan anggota organisasi. Gaya kepemimpinan participative ini cocok apabila tujuan perusahaan telah dikomunikasikan dan para bawahan telah menerimanya. Penelitian mengenai gaya kepemimpinan participative terhadap kinerja karyawan pernah dilakukan oleh Fitriani (2013). Berdasarkan hal tersebut dalam penelitian ini dapat dirumuskan hipotesis sebagai berikut :

H2: Gaya kepemimpinan participative berpengaruh signifikan dan positif terhadap kinerja karyawan.

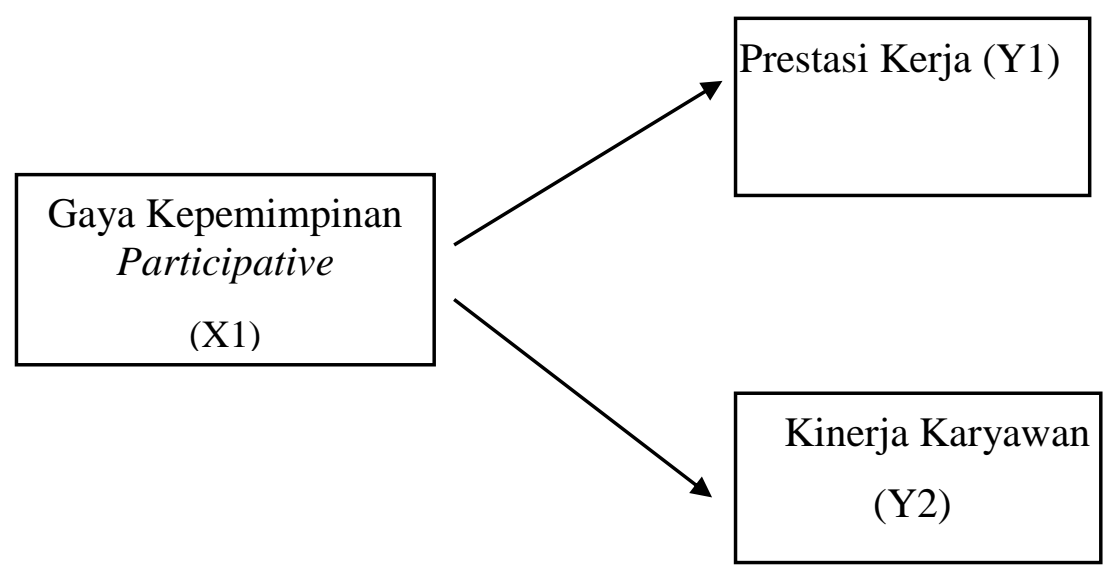

Gambar 2. Model Rerangka Konseptual Penelitian

Pengembangan Hipotesis. Menurut Sugiyono (2009) hipotesis merupakan jawaban atau dugaan sementara terhadap masalah penelitian yang kebenarannya masih harus diuji secara empiris. Hipotesis dalam penelitian ini antara lain :

$\mathrm{H}_{1}$ : Diduga Gaya Kepemimpinan Participative berpengaruh terhadap Prestasi Kerja

$\mathrm{H}_{2}$ : Diduga Gaya Kepemimpinan Participative berpengaruh terhadap Kinerja Karyawan

\section{METODE}

Waktu dan Tempat Penelitian. Proses penelitian ini diawali dengan kegiatan mengidentifikasi permasalahan di tempat yang akan digunakan sebagai lokasi penelitian, perumusan masalah yang teridentifikasi, pengumpulan dasar teori yang memperkuat landasan dalam variabel, penyusunan metode dalam pengumpulan data, penyusunan 
instrumen, hingga penentuan teknik pengujian statistik yang dipergunakan. Pada proses ini dibutuhkan waktu penelitian sejak Februari sampai Juni 2017.

Desain Penelitian. Peneliti harus mengikuti aturan-aturan metode ilmiah yang ada dalam melakukan suatu penelitian ilmiah. Untuk menerapkan metode ilmiah dalam penelitian maka diperlukan suatu desain penelitian.

Dalam penelitian ini, penulis menggunakan metode penelitian kausal. Menurut Sugiyono (2013) metode penelitian kausal adalah melihat hubungan variabel terhadap objek yang diteliti bersifat sebab akibat, sehingga dalam penelitiannya ada variabel independen (eksogen) dan variabel dependen (endogen). Dalam hal ini penelitian bertujuan untuk mengetahui Pengaruh Gaya Kepemimpinan ParticipativeTerhadap Prestasi Kerja dan Kinerja Karyawan Pada Divisi Sales Support Pada PT Hero Supermarket Tbk. Bintaro.

Populasi dan Sampel Penelitian. Menurut Sugiyono (2013) populasi adalah wilayah generalisasi yang terdiri atas obyek atau subyek yang mempunyai kualitas dan karakteristik tertentu yang ditetapkan oleh peneliti untuk dipelajari dan kemudian ditarik kesimpulan.Berdasarkan pada tempat penelitian yang telah ditetapkan, maka populasi yang dijadikan objek dalam penelitian yaitu karyawan dari divisi Sales Supportpada PT Hero Supermarket Tbk. Bintaro yang berjumlah 70 karyawan.

Sampel dan Metode Pengambilan Sampel. Menurut Sugiyono (2013) sampel adalah bagian dari jumlah dan karakteristik yang dimiliki oleh populasi tersebut. Untuk menentukan sampel dalam penelitian di PT Hero Supermarket Tbk. Bintaro dari satu divisi yang populasinya berjumlah 70 karyawan. Samplingjenuh adalah teknik penentuan sampel dimana semua anggota populasi dijadikan sebagai sampel.Maka jumlah sampel yang digunakan yaitu 70 responden.

Teknik Pengumpulan Data. Metode pengumpulan data yang digunakan dalam penelitian ini dengan metode pengumpulan data penelitian keperpustakaan (library research) dan penelitian lapangan (field research). Penelitian keperpustakaan dilakukan untuk memperoleh data mengenai teori yang mendukung penelitian. Sementara itu, penelitian lapangan dilakukan untuk mengetahui kondisi yang terjadi dilapangan secara lebih jelas dan membandingkan dengan teori yang telah didapatkan.

Teknik Pengumpulan Data. Teknik pengumpulan data dalam penelitian ini dengan melakukan observasi dan survey secara langsung pada objek penelitian, yaitu karyawan di PT Hero Supermarket Tbk. Bintaro pada divisi Sales Support.

Instrumen pengumpulan data yang digunakan adalah kuesioner. Kuesioner merupakan instrumen pengumpulan data yang dilakukan dengan cara memberi seperangakat pertanyaan atau pernyataan tertulis kepada responden untuk dijawabnya (Sugiyono, 2013). Jenis data yang digunakan oleh penulis adalah data primer berupa hasil pengisian kuesioner dari karyawan divisi Sales Support pada PT Hero Supermarket Tbk. Bintaro mengenai Pengaruh Gaya Kepemimpinan Participative Terhadap Prestasi Kerja dan Kinerja Karyawan.

Metode Analisis Data. Metode analisis data dalam penelitian ini menggunakan Component atau Variance Based Structural Equation Modelingdimana dalam pengolahan 
datanya menggunakan program Partial Least Square(Smart-PLS) versi 3.0. PLS (Partial Least Square) adalah model dari variance based SEM. PLS dimaksudkan untuk causalperdictive analysis dalam situasi kompleksitas yang tinggi dan dukungan teori yang rendah (Ghozali: 2014).

\section{HASIL DAN PEMBAHASAN}

Metode Analisis Data Partial Least Square (PLS). Partial Least Square merupakan metode analisis Component / Variance Based Structural Equation Modelingdimana dalam pengelohan datanya menggunakan program Partial Least Square (Smart-PLS) versi 3.0. PLS (Partial Least Sqaure) adalah model alternative dari covariance based SEM. PLS dimaksudkan untuk causal-predictive analysis dalam situasi kompleksitas yang tinggi dan dukungan teori yang rendah (Ghozali, 2014). PLS memiliki tujuan untuk mencari hubungan linear prediktif optimal yang ada pada data. Walaupun PLS dapat juga digunakan untuk mengkonfirmasi teori, tetapi dapat juga digunakan menjelaskan ada atau tidaknya hubungan antar variabel laten. Seperti dinyatakan oleh Wold dalam Ghozali (2014) Partial Least Square (PLS) merupakan metode analisis yang powerfull oleh karena tidak didasarkan banyak asumsi, data tidak harus terdistribusi normal multivariate, dan sample tidak harus besar. Langkah-langkah pengujian yang akan dilakukan sebagai berikut:

\section{Evaluasi Measurement Model (Outer Model)}

a. Convergent Validity. Pengujian Convergent Validity dari masing-masing indikator konstruk. Menurut Chin dalam Ghozali (2014), suatu indikator dikatakan mempunyai valid yang baik jika nilainya lebih besar dari 0,70 , sedangkan loading factor 0,50 sampai 0,60 dapat dianggap cukup. Berdasarkan kriteria ini bila ada loading factor dibawah 0,50 maka akan di drop dari model. Dengan melihat hasil output korelasi antara indikator, dengan konstruksinya seperti dilihat di Tabel 2 dan Gambar 2 dibawah ini:

Tabel 2. Hasil Pengujian Convergent Validity

\begin{tabular}{|c|c|c|c|c|}
\hline Indikator & $\begin{array}{c}\text { Gaya } \\
\text { Kepemimpinan } \\
\text { Participative }\end{array}$ & $\begin{array}{c}\text { Prestasi } \\
\text { Kerja }\end{array}$ & $\begin{array}{c}\text { Kinerja } \\
\text { Karyawan }\end{array}$ & Keterangan \\
\hline GKP1 & 0.821 & & & Valid \\
\hline GKP2 & 0.793 & & & Valid \\
\hline GKP3 & 0.028 & & & Tidak Valid \\
\hline GKP4 & 0.225 & & & Tidak Valid \\
\hline GKP5 & 0.833 & & & Valid \\
\hline GKP6 & 0.877 & & & Valid \\
\hline GKP7 & 0.870 & & & Valid \\
\hline GKP8 & 0.848 & & & Valid \\
\hline GKP9 & 0.476 & & & Tidak Valid \\
\hline GKP10 & 0.362 & & & Tidak Valid \\
\hline PK1 & & 0.822 & & Valid \\
\hline PK2 & & 0.274 & & Tidak Valid \\
\hline PK3 & & 0.384 & & Tidak Valid \\
\hline PK4 & & 0.834 & & Valid \\
\hline
\end{tabular}




\begin{tabular}{|c|c|c|c|}
\hline PK5 & 0.822 & & Valid \\
\hline PK6 & 0.851 & & Valid \\
\hline PK7 & 0.831 & & Valid \\
\hline PK8 & 0.420 & & Tidak Valid \\
\hline PK9 & 0.190 & & Tidak Valid \\
\hline KK1 & & 0.799 & Valid \\
\hline KK2 & & 0.005 & Tidak Valid \\
\hline KK3 & & 0.244 & Tidak Valid \\
\hline KK4 & & 0.901 & Valid \\
\hline KK5 & & 0.827 & Valid \\
\hline KK6 & & 0.876 & Valid \\
\hline KK7 & & 0.812 & Valid \\
\hline KK8 & & 0.442 & Tidak Valid \\
\hline KK9 & & 0.324 & Tidak Valid \\
\hline KK10 & & 0.366 & Tidak Valid \\
\hline
\end{tabular}

Sumber: Output PLS

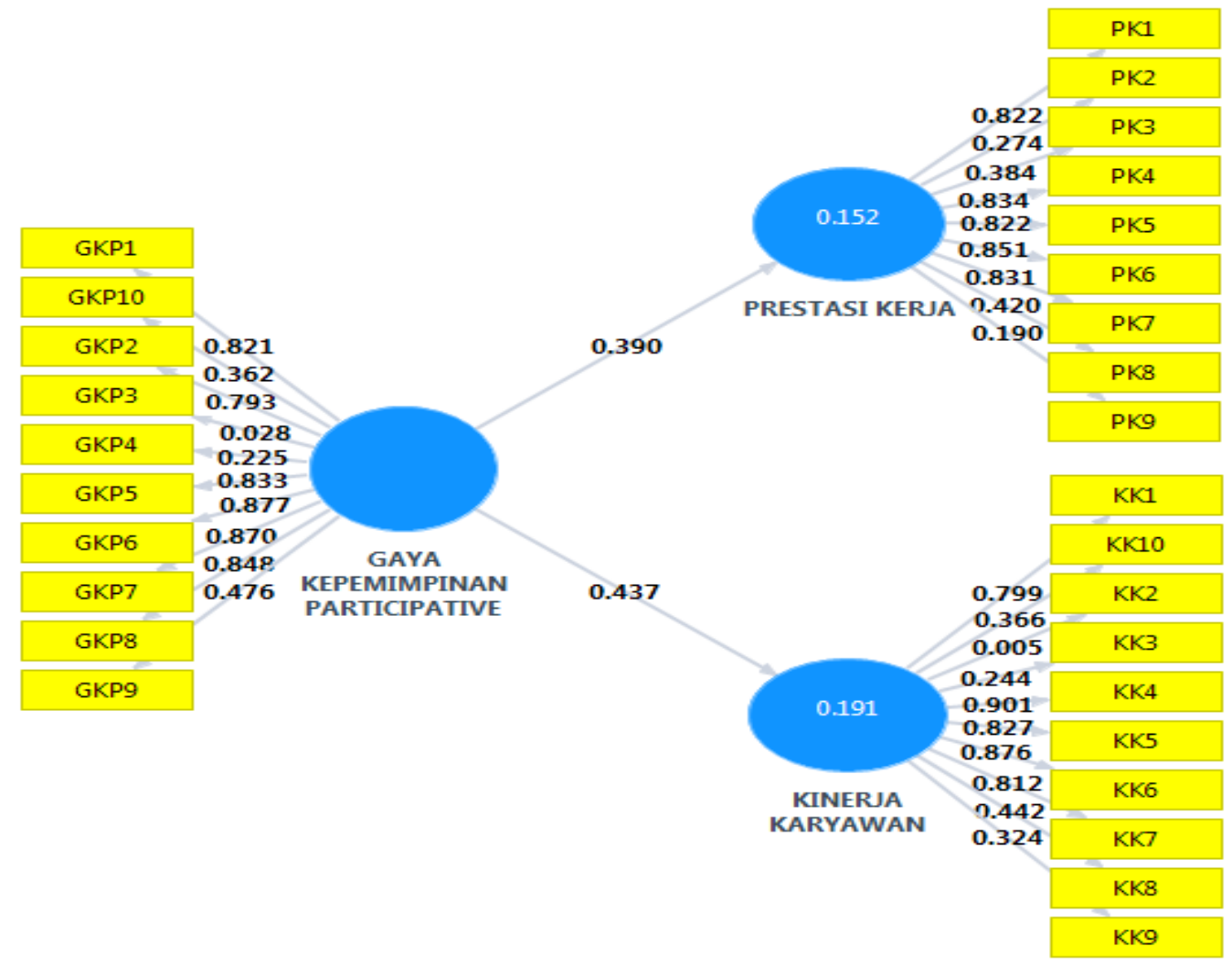

Gambar 2. Hasil Algoritma PLS

Sumber: Output PLS

Berdasarkan dari Tabel 2 dan Gambar 2 diatas, terlihat bahwa indikator GKP3, GKP4, GKP9, GKP10, PK2, PK3, PK8, PK9, KK2, KK3, KK8, KK9, KK10memiliki nilai loading faktor kurang dari 0,60 tidak signifikan. Oleh karena itu, indikator tersebut akan dihilangkan dari model. Berikut hasil output dari perhilangan indikator dan perhitungan kembali. 
Tabel 3. Hasil Pengujian Convergent Validity (Modifikasi)

\begin{tabular}{|c|c|c|c|c|c|}
\hline & $\begin{array}{l}\text { Ind } \\
\text { or }\end{array}$ & $\begin{array}{c}\text { Gaya } \\
\text { Kepemimpinan } \\
\text { Participative }\end{array}$ & $\begin{array}{c}\text { Prestasi } \\
\text { Kerja }\end{array}$ & $\begin{array}{c}\text { Kinerja } \\
\text { Karyawan }\end{array}$ & Keterangan \\
\hline & GK & 0.836 & & & Valid \\
\hline & GK & 0.803 & & & Valid \\
\hline$P 2$ & GK & 0.838 & & & Valid \\
\hline P5 & GK & 0.879 & & & Valid \\
\hline P6 & GK & 0.878 & & & Valid \\
\hline P8 & GK & 0.852 & & & Valid \\
\hline 1 & PK & & 0.8 & & Valid \\
\hline 4 & PK & & 0.8 & & Valid \\
\hline 5 & PK & & 0.8 & & Valid \\
\hline 6 & PK & & 0.8 & & Valid \\
\hline 7 & PK & & 0.8 & & Valid \\
\hline 1 & KK & & & 0.79 & Valid \\
\hline 4 & KK & & & 0.89 & Valid \\
\hline 5 & KK & & & 0.84 & Valid \\
\hline 6 & KK & & & 0.88 & Valid \\
\hline 7 & $\mathrm{KK}$ & & & 0.82 & Valid \\
\hline
\end{tabular}

Sumber: Output PLS 


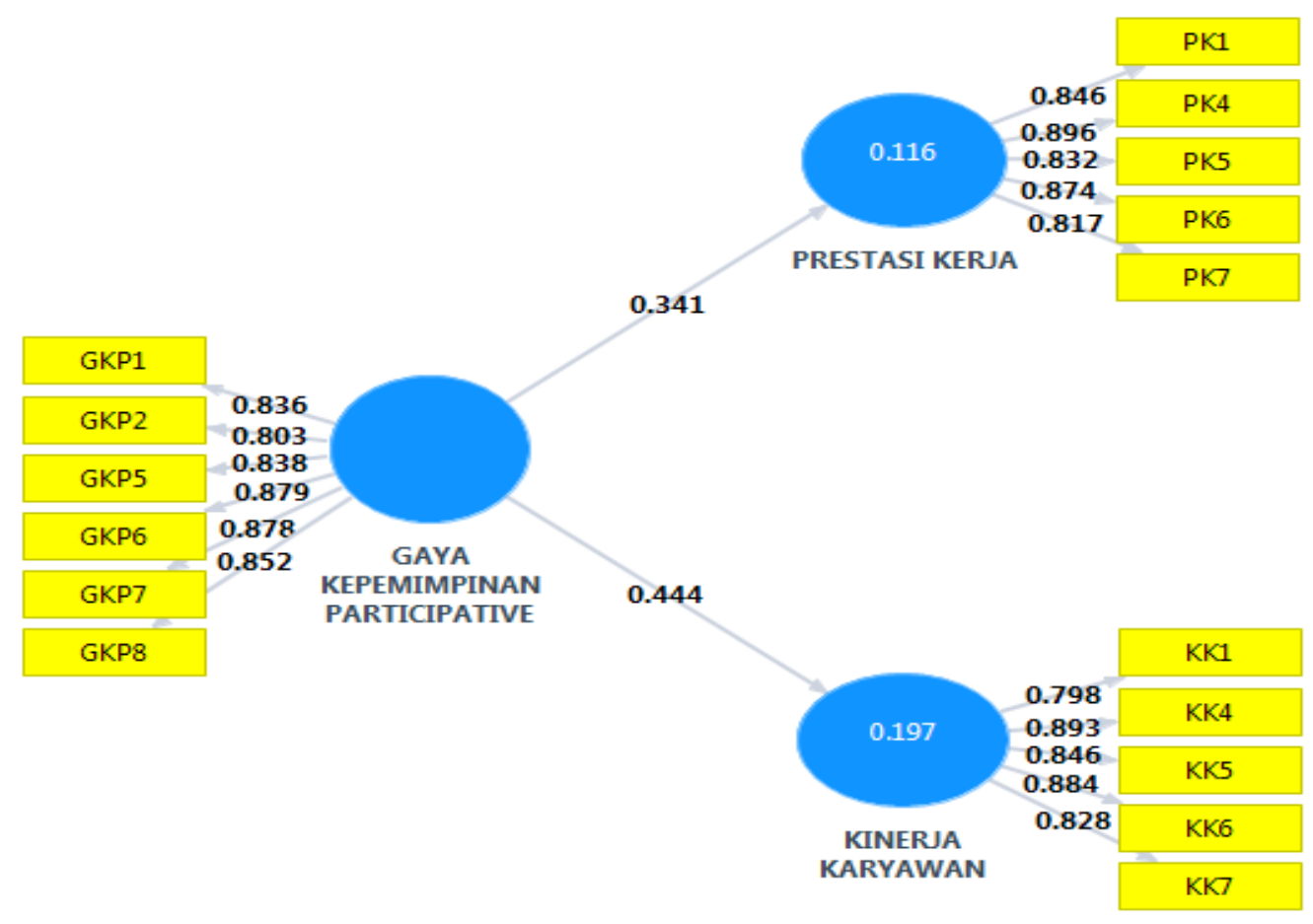

Gambar 4. Hasil Algoritma PLS (Modifikasi)

Sumber : Output PLS

Hasil dari modifikasi pengujian Convergent Validity pada Tabel 4.10 dan Gambar 4.2 diatas, dapat dilihat bahwa semua indikator telah memenuhi Convergent Validity karena memiliki nilai factor loading diatas 0.60

b. Discriminant Validity. Pengujian discriminant validity, indikator reflektif dapat dilihat pada cross loading antara indikator dengan konstruknya. Suatu indikator dinyatakan valid jika mempunyai loading factor lebih besar dibandingkan dengan konstruk lain. Dengan demikian, konstruk laten memprediksi indikator pada blok mereka lebih baik dibandingkan dengan indikator blok lain.

Tabel 4. Hasil Pengujian Discriminant Validity(Cross Loadings)

\begin{tabular}{|c|c|c|c|c|}
\hline & & $\begin{array}{c}\text { Gaya Kepemimpinan } \\
\text { Participative }\end{array}$ & Prestasi Kerja & Kinerja Karyawan \\
\hline \multirow{3}{*}{ P1 } & GK & 0,836 & & \\
\hline & & & 0,348 & 0,319 \\
\hline & GK & 0,803 & & \\
\hline \multirow[t]{2}{*}{$\mathrm{P} 2$} & & & 0,304 & 0,337 \\
\hline & GK & 0,838 & & \\
\hline P5 & & & 0,298 & 0,340 \\
\hline P6 & Un & , o, & 0,357 & 0,503 \\
\hline \multirow[t]{2}{*}{ P7 } & GK & 0,878 & 0,221 & 0,349 \\
\hline & GK & 0,852 & 0,159 & 0,366 \\
\hline
\end{tabular}




\begin{tabular}{lllll} 
P8 & PK & 0,370 & 0,846 & 0,224 \\
1 & PK & 0,335 & 0,896 & \\
4 & PK & 0,206 & 0,832 & 0,314 \\
5 & & 0,874 & 0,237 \\
6 & PK & 0,279 & & 0,237 \\
\hline
\end{tabular}

Sumber : Output PLS

\begin{tabular}{|c|c|c|c|}
\hline & $\begin{array}{c}\text { Gaya Kepemimpinan } \\
\text { Participative }\end{array}$ & Prestasi Kerja & $\begin{array}{c}\text { Kinerja } \\
\text { Karyawan }\end{array}$ \\
\hline PK7 & 0,161 & 0.817 & 0,171 \\
\hline KK1 & 0,312 & 0,237 & 0,798 \\
\hline KK4 & 0,484 & 0,355 & 0,893 \\
\hline KK5 & 0,352 & 0,246 & 0,846 \\
\hline KK6 & 0,394 & 0,285 & 0,884 \\
\hline KK7 & 0,297 & 0,012 & 0,828 \\
\hline
\end{tabular}

Sumber: Output PLS

Berdasarkan dari Tabel 4 terlihat bahwa loading factor gaya kepemimpinan participative lebih besar dibandingkan dengan konstruk lain (GKP1 0.836, GKP2 sebesar 0.803, GKP5 sebesar 0.838, GKP6 sebesar 0.879, GKP7 sebesar 0.878, GKP8 sebesar 0.852) sehingga indikator gaya kepemimpinan participative dapat dikatakan valid. Selanjutnya untuk loading factor prestasi kerja lebih besar dibandingkan dengan konstruk lain (PK1 sebesar 0.846, PK4 sebesar 0.896, PK5 sebesar 0.832, PK6 sebesar 0.874, PK7 sebesar 0.817) sehingga indikator prestasi kerja dapat dikatakan valid. Begitu pula dengan loading factor kinerja karyawan lebih besar dibandingkan dengan konstruk lain (KK1 sebesar 0.798, KK4 sebesar 0.893, KK5 sebesar 0.846, KK6 sebesar 0.884, KK7 sebesar 0.828) sehingga indikator kinerja karyawan dapat dikatakan valid. Hal ini menunjukkan bahwa konstruk laten memprediksi indikator blok mereka lebih baik dibandingkan dengan indikator di blok lainnya.

Metode lain untuk melihat discriminant validity adalah dengan melihat nilai square root of average variance extracted (AVE) setiap konstruk dengan korelasi antara konstruk dengan konstruk lainnya dalam model, maka dapat dikatakan memiliki nilai discriminant validity yang baik.

Tabel 5. Hasil Pengujian AVE

\begin{tabular}{cc}
\hline Variabel & AVE \\
\hline Gaya Kepemimpinan Participative & 0.719 \\
Prestasi Kerja & 0.728 \\
Kinerja Karyawan & 0.724
\end{tabular}

Sumber: Output PLS

Uji Reliabilitas (Composite Reliability dan Cronbach's Alpha). Pengujian Descriminant validity yaitu suatu indikator dinyatakan valid jika mempunyai loading factor tertinggi 
kepada konstruk yang dituju pengukurannya lebih besar dari pada ukuran konstruk lainnya, maka hal ini menunjukan bahwa konstruk laten memprediksi indikator pada blok mereka lebih baik dibandingkan dengan ukuran pada blok lainnya. Metode lain untuk melihat discriminant validity adalah dengan dilakukan uji reliabilitas konstruk yang diukur melalui dua kriteria yaitu composite realibility dan cronbachs alpha dari indikator yang mengukur konstruk. Composite Realibility bertujuan untuk menguji validitas instrumen dalam suatu model penelitian. Atau mengukur internal consistency dan nilai nilainya harus diatas 0.60. apabila seluruhnya nilai variabel laten memiliki nilai composite realibility maupun cronbachs alpha $\geq 0.70$ hal itu berarti bahwa konstruk memiliki reabilitas yang baik atau kuesioner yang digunakan sebagai alat dalam penelitian ini telah handal atau konsisten.

Tabel 6. Hasil Pengujian Composite Reliability

\begin{tabular}{ccc}
\hline Variabel & $\begin{array}{c}\text { Composite } \\
\text { Reliabilitas }\end{array}$ & Keterangan \\
\hline Gaya Kepemimpinan Participative & 0,939 & Reliabel Tinggi \\
Prestasi Kerja & 0,930 & Reliabel Tinggi \\
Kinerja Karyawan & 0,929 & Reliabel Tinggi \\
\hline
\end{tabular}

Sumber : Output PLS

Tabel 7. Hasil Pengujian Cronbachs Alpha

\begin{tabular}{ccc}
\hline Variabel & Cronbachs Alpha & Keterangan \\
\hline Gaya Kepemimpinan Participative & 0,922 & Reliabel Tinggi \\
Prestasi Kerja & 0,911 & Reliabel Tinggi \\
Kinerja Karyawan & 0,905 & Reliabel Tinggi \\
\hline
\end{tabular}

Sumber: Output PLS

Berdasarkan Tabel tersebut dapat diuraikan bahwa hasil pengujian composite reliability dan cronbachs alpha pada Tabel 7 dan Tabel 8 menunjukkan nilai yang memuaskan karena variabel menunjukkan nilai rata-rata setiap variabel diatas 0.70. Menurut Guilford dalam Suherman (2003) menggunakan derajat reliabilitas sebagai berikut:

$\begin{array}{ll}0.90-1.00 & \text { Derajat reliabilitas sangat tinggi } \\ 0.70-0.90 & \text { Derajat reliabilitas tinggi } \\ 0.40-0.70 & \text { Derajat reliabilitas sedang } \\ 0.20-0.40 & \text { Derajat reliabilitas rendah } \\ 0.00-0.20 & \text { Derajat reliabilitas sangat rendah }\end{array}$

Berdasarkan derajat reliabilitas diatas maka, nilai composite reliability dan cronbachs alpha variabel, gaya kepemimpinan participative, prestasi kerja dan kinerja karyawan mempunyai nilai yaitu 0.70-0.90 dapat dikatakan reliabel sebab nilai tersebut berada pada derajat reliabilitasnya yang tinggi.

Pengujian Model Struktural/Uji Hipotesis (Inner Model). Pengujian inner model adalah pengembangan model berbasis konsep dan teori dalam rangka menganalisis hubungan antara variabel independen dan dependen telah dijabarkan dalam kerangka 
konseptual. Langkah-langkah pengujian terhadap model struktural (inner model) adalah sebagai berikut:

R-Square. Melihat nilai R-square yang merupakan uji goodness-fit model.

Tabel 8. Nilai R² Variabel Endogen

\begin{tabular}{lc}
\hline & R Square \\
\hline Prestasi Kerja & 0,116 \\
Kinerja Karyawan & 0,197 \\
\hline
\end{tabular}

Sumber : Output PLS.

Model struktural mengindikasi bahwa model pada variabel Prestasi Kerja, dan Kinerja Karyawan dapat dikatakan lemah karena memiliki nilai 0.19 dan dibawah 0.19. Model pengaruh variabel laten independen Gaya Kepemimpinan Participative terhadap Prestasi Kerja memberikan nilai R-square sebesar 0.116 yang dapat diinterprestasikan bahwa variabilitas konstruk Prestasi Kerja yang dapat dijelaskan oleh variabilitas konstruk Gaya Kepemimpinan Participative sebesar $11.6 \%$ sedangkan $88.4 \%$ dijelaskan oleh variabel lain diluar yang diteliti. Kemudian model pengaruh variabel laten independen Gaya Kepemimpinan Participative terhadap Kinerja Karyawan memberikan nilai Rsquare sebesar 0.197 yang dapat diinterprestasikan bahwa variabilitas konstruk Kinerja Karyawan yang dapat dijelaskan oleh variabilitas Gaya Kepemimpinan Participative sebesar $19.7 \%$ sedangkan $80.3 \%$ dijelaskan oleh variabel lain diluar yang diteliti.

Goodness of FitModel. Pengujian Goodness of Fit model struktural pada inner model menggunakan nilai predictive-relevance (Q2). Nilai $Q$-square lebih besar 0 (nol) menunjukan bahwa model mempunyai nilai predictive relevance.

Nilai R-square tiap-tiap variabel endogen dalam penelitian ini dapat dilihat pada perhitungan berikut ini:

$$
\begin{aligned}
& \text { Nilai predictive-relevance diperoleh dengan rumus: } \\
& \mathrm{Q}^{2}=1-(1-\mathrm{R} 1)(1-R p) \\
& \mathrm{Q}^{2}=1-(1-0.116)(1-0.197) \\
& \mathrm{Q}^{2}=1-(0.884)(0.803) \\
& \mathrm{Q}^{2}=1-0.7098 \\
& \mathrm{Q}^{2}=0,2902
\end{aligned}
$$

Hasil perhitungan diatas memperlihatkan nilai predictive relevance sebesar 0,2902>0. Hal itu berarti bahwa 29,02\% variasi pada variabel prestasi kerja, kinerja karyawan (dependen variabel) dijelaskan oleh variabel independen yang digunakan. Dengan demikian model dikatakan layak untuk memiliki nilai prediktif yang relevan.

Hasil Pengujian Hipotesis (Estimasi Koefisien Jalur). Nilai estimasi untuk hubungan jalur dalam model structural harus signifikan nilai signifikansi ini dapat diperolah dengan prosedur boostrapping. Melihat signifikansi pada hipotesis dengan melihat nilai koefisien parameter dan nilai signifikansi t statistic pada algorithm boostrapping report. Untuk mengetahui signifikan atau tidak signifikan dilihat dari t-table pada alpha $0,05(5 \%)=$ 1,96, kemudian t-table dibandingkan oleh t-hitung (t-statistik). 
Tabel 9. Hasil Uji Hipotesis

\begin{tabular}{|c|c|c|c|c|c|}
\hline & $\begin{array}{l}\text { Original } \\
\text { Sample } \\
\text { (O) }\end{array}$ & $\begin{array}{l}\text { Standard } \\
\text { Deviation }\end{array}$ & $\begin{array}{c}\mathrm{T} \\
\text { Statistics }\end{array}$ & $\begin{array}{c}\mathrm{P} \\
\text { Values }\end{array}$ & Keterangan \\
\hline $\begin{array}{l}\text { Gaya } \\
\text { Kepemimpinan Participative } \\
\text {-> Prestasi Kerja }\end{array}$ & 0.341 & 0.079 & 4.338 & 0.000 & $\begin{array}{l}\text { Positif- } \\
\text { Signifikan }\end{array}$ \\
\hline $\begin{array}{l}\text { Gaya Kepemimpinan } \\
\text { Participative } \\
\text {-> Kinerja Karyawan }\end{array}$ & 0.444 & 0.126 & 3.516 & 0.000 & $\begin{array}{l}\text { Positif- } \\
\text { Signifikan }\end{array}$ \\
\hline
\end{tabular}

Sumber: Output PLS

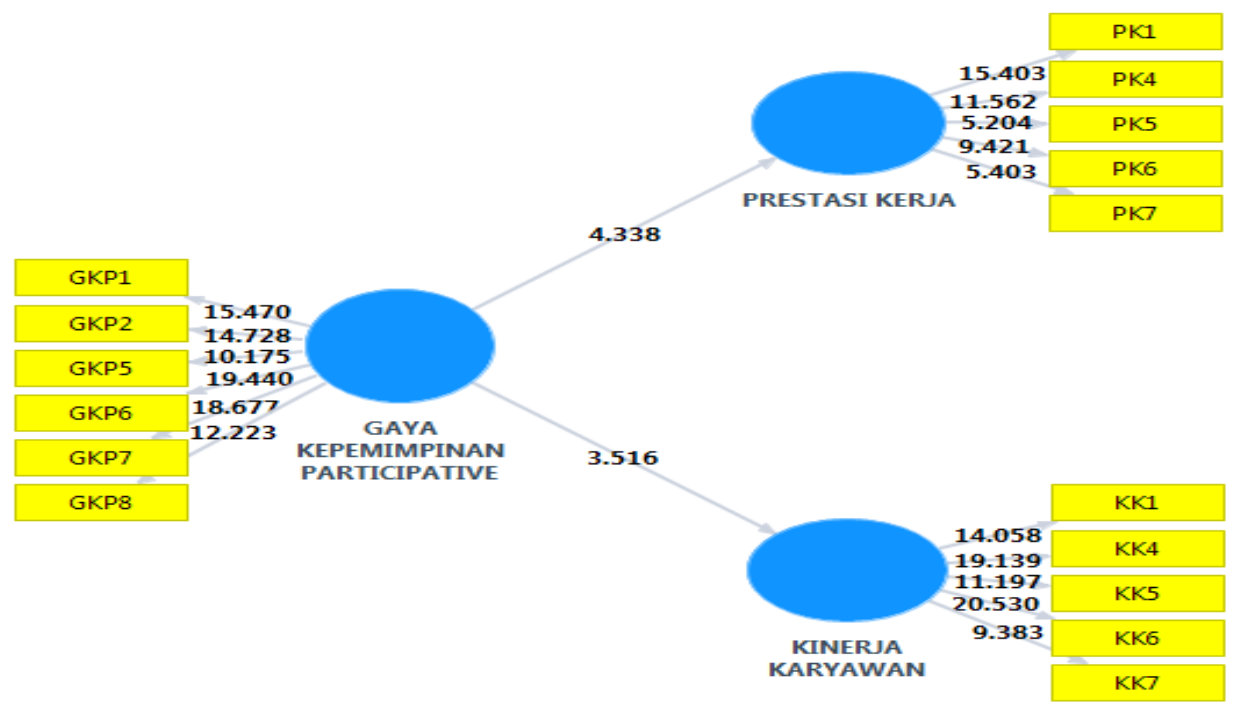

Gambar 5. Hasil Bootstrapping (Hasil Uji Hipotesis)

Sumber: Output PLS

Pembahasan. Pengaruh Gaya Kepemimpinan Participative Terhadap Prestasi Kerja. Berdasarkan uji hipotesis yang sudah didapat penelitian ini diperoleh hasil nilai T-Statistic sebesar 4.338dan Original Sample 0.341. Nilai T-Statistic lebih dari nilai T-table 1.96 dan nilai original sample menunjukkan nilai positif, hasil ini menunjukkan bahwa gaya kepemimpinan participative berpangaruh positif dan signifikan terhadap prestasi kerja.Hal ini menunjukkan bahwa cukup besar peranan faktor kepemimpinan partisipatif atas prestasi kerja. Pimpinan perlu menerapkan gaya kepemimpinan pada orientasi tugas dimana pimpinan perlu memberikan arahan kepada bawahannya sebelum melaksanakan pekerjaannya, menetapkan peraturan yang harus dilaksanakan atau ditaati sehingga tujuan dari perusahaan yang sudah ditetapkan dapat tercapai. Hal ini menunjukkan apabila pimpinan dapat terbuka dalam menerima saran dari bawahan dan bermusyawarah sebelum mengambil keputusan maka prestasi kerja karyawan di PT Hero Supermarket Tbk. Bintaro divisi sales support akan meningkat. Hasil hipotesis ini sependapat dengan hasil penelitian Djoko Soelistya (2014) yang menyimpulkan bahwa gaya kepemimpinan participative 
berpengaruh positif dan signifikan terhadap prestasi kerja. Dan juga menurut Selly Partiningsih (2014).

Pengaruh Gaya Kepemimpinan Participative Terhadap Kinerja Karyawan. Berdasarkan hasil hipotesis yang sudah didapat pada penelitian ini diperoleh hasil nilai TStatistic sebesar 3.516 dan Original Sample 0.444. Nilai T-Statistic lebih dari nilai T-table 1.96 dan nilai original sample menunjukkan nilai positif, hasil ini menunjukkan bahwa gaya kepemimpinan participative berpengaruh positif dan signifikan terhadapp kinerja karyawan. Hal ini menunjukkan bahwa gaya kepemimpinan participative dilakukan atau ditingkatkan kembali oleh pimpinan. Peranan pimpinan ini sangat berperan penting bagi karyawan dalam melaksanakan pekerjaan didalam perusahaan, penerapan Gaya Kepemimpinan yang berorientasi tugas maupun yang berorientasi hubungan dengan bawahan perlu disesuaikan dengan situasi dan kondisi yang ada dalam perusahaan. Gaya kepemimpinan participative yang diterapkan akan memberikan dampak terhadap hasil kerja karyawan untuk tercapainya tujuan-tujuan perusahaan, dan untuk mewujudkan perkembangan perusahaan dalam bersaing. Hal ini sependapat dengan hasil penelitian yang di lakukan oleh Fitriani (2013) yang menyatakan bahwa gaya kepemimpinan participative mempunyai pengaruh positif terhadap kinerja pegawai pada Dinas Pendidikan Provinsi Kalimantan Timur dan juga menurut Syaiful Arifin dan Basworo Dibyo (2016).

\section{PENUTUP}

Simpulan. Penelitian ini mencoba menganalisis variabel-variabel yang berkaitan dengan gaya kepemimpinan participative terhadap prestasi kerja dan kinerja karyawan. Hasil diperoleh dari penelitian pada karyawan pada PT Hero Supermarket Tbk. Bintaro pada divisi sales support. Dari hasil penelitian yang telah diperoleh dari perhitungan Partial Least Square (PLS), maka dapat di tarik kesimpulan sebagai berikut: (1) Gaya Kepemimpinan Participative berpengaruh positif dan signifikan terhadap prestasi kerja PT Hero Supermarket Tbk. Bintaro divisi sales support; (2) Gaya Kepemimpinan Participative berpengaruh positif dan signifikan terhadap kinerja karyawan PT Hero Supermarket Tbk. Bintaro divisi sales support.

Saran. Berdasarkan hasil penelitian ini, pembahasan dan kesimpulan, maka peneliti memberikan saran-saran sebagai berikut:

1) Saran untuk PT Hero Supermarket Tbk. Bintaro divisi Sales Support. Pihak PT Hero Supermarket Tbk. Bintaro divisi Sales Support disarankan untuk dapat menggunakan penelitian ini untuk bahan referensi terhadap perbaikan-perbaikan yang berhubungan dengan:

a. Gaya Kepemimpinan Participative terhadap prestasi kerja diharapkan agar pihak perusahaan mampu menerapkan berbagai kebijakan yang berkaitan dengan Gaya Kepemimpinan Participative, sehingga untuk meningkatkan gaya kepemimpinan participative pimpinan harus selalu mengevaluasi kelebihan dan kekurangan dari kepemimpinan yang diterapkan di perusahaan dan lebih memberikan arahan dalam pemberian tugas agar sistem kepemimpinan yang diterapkan tepat sasaran dan diharapkan kedepannya agar semakin baik. Pimpinan maupun karyawan menciptakan suasana yang harmonis, sehingga dapat menciptakan komunikasi 
dua arah yang lebih baik. Hal ini bertujuan agar karyawan dapat meningkatkan prestasi kerjanya.

b. Gaya Kepemimpinan Participativeterhadap kinerja karyawan diharapkan agar pihak perusahaan mampu menerapkan berbagai kebijakan yang berkaitan dengan Gaya Kepemimpinan Participative, sehingga untuk meningkatkan gaya kepemimpinan Participativeterhadap kinerja karyawan, pemimpin harus memberikan perhatian terhadap para karyawan dalam menjalankan tugasnya dan dapat menerima masukan atau ide yang diberikan karyawan untuk tujuan perusahan dan pimpinan selalu memotivasi karyawan agar meningkatkan pengetahuan dan keterampilan karyawan serta memberikan kesempatan kepada karyawan untuk melakukan pengembangan dan perkembangan pribadi secara mandiri, sehingga kinerja karyawan yang belum tercapai dapat menjadi lebih optimal.

2) Saran untuk Peneliti Selanjutnya. Berdasarkan apa yang penulis lakukan diharapkan untuk peneliti selanjutnya menambahkan beberapa point yang penulis harapkan yaitu:

a. Saran untuk peneliti selanjutnya, sebaiknya bisa lebih mengembangkan variabel dan indikator yang belum digunakan didalam penelitian ini sehingga peneliti disarankan untuk lebih meningkatkan dalam membaca referensi-referensi yang tersedia seperti jurnal, dan juga penulis menyarankan untuk penelitan selanjutnya yaitu dengan memilih tempat penelitian lainnya misalnya seperti bank, rumah sakit atau sekolah.

\section{DAFTAR RUJUKAN}

A. A Anwar Prabu Mangkunegara. (2009). Manajemen Sumber Daya Manusia. Bandung: PT Remaja Rosdakarya.

Amirullah. (2015). Pengantar Manajemen. Jakarta. Penerbit: Mitra Wacana Media.

Angka Priatna, Hendra Muda Nasution. (2015) "Hubungan Gaya Kepemimpinan Partisipatif Dengan Kinerja Karyawan Pada PT Tirtatama Elpindo". Jurnal Ilmiah Manajemen Fakultas Ekonomi. 1 (2), 68-78.

Bohlander, George., and Snell, Scott. (2010) Principles of Human Resource Management, 15th ed. Mason, OH: South Western - Cengage Learning.

Daft, Richard L. (2010). Era Baru Manajemen. Jakarta: Salemba Empat.

Djoko Soelistya. (2014). "Pengaruh Gaya Kepemimpinan Partisipatif dan

Komunikasi Terhadap Motivasi Kerja serta Dampaknya pada Prestasi Kerja Pegawai di Maspion Group Surabaya Jawa Timur". Jurnal Ilmu Ekonomi dan Manajemen. 1 (1), 1-10.

Dr. Mehrabi Javad, Nematollah Safaei, Dr.Ali Kazemi. (2013). "Studying the Effec of Leader's Participative Behaviors on Employee's Effectiveness Perception and Performance(Kohdasht Municipality as Case Study)". International Journal of Academic Research in Business and Social Sciences. 3 (1), 140-152.

Firdaus, Muhammad Rizal. (2013). "Pengaruh Gaya Kepemimpinan Dan MotivasiTerhadap Prestasi Kerja Karyawan Pusat Teknologi Konversi DanKonservasi Energi BPPT”. Skripsi. Universitas Mercu Buana. 
Fitriani. (2013) "Pengaruh Gaya Kepemimpinan Partisipatif Terhadap KinerjaPegawai Pada Dinas Pendidikan Provinsi Kalimantan Timur". eJournalAdministrasi Negara. 1 (3), 989-102.

Handoko, T. Hani. (2006). Manajemen Personalia dan Sumber Daya Manusia.Yogyakarta: BPFE.

Hasibuan, M. (2007). Manajemen Sumber Daya Manusia. Jakarta : Bumi Aksara.

Hasibuan, Malayu S. P. (2008). Manajemen Sumber Daya Manusia. Jakarta: Bumi Aksara.

Hasibuan, Melayu. (2011). Manajemen, Dasar, Pengertian, dan Masalah.Jakarta: Ghalia Indonesia.

Hendra. (2007) "Pengaruh Gaya Kepemimpinan Terhadap Kinerja Karyawan Pada PT. PLN Cabang Blitar". Skripsi. Universitas Muhammadiyah Malang.

Herujito, Yayat M. (2006). Dasar-Dasar Manajamen. Jakarta: PT Grasindo.

Hutapea, Parulian dan Nurianna Thoha. (2008). Kompetensi Plus. Jakarta: PT Gramedia Pustaka Utama.

Insan, Pribadi Darmawan. (2015). "Pengaruh Gaya Kepemimpinan Partisipatif, Lingkungan Kerja, Kompensasi Dan Budaya Organisasi Terhadap Kinerja Karyawan". Skripsi. Universitas Diponegoro Semarang.

Justine T, Sirait. (2006). Memahami Aspek-Aspek Pengelolaan Sumber Daya Manusia Dalam Organisasi, Penerbit Grasindo: Jakarta.

Lumbasi, George W, Dr. George O. K'Aol, Dr. Caren A. Ouma (2016). “The Effect Of Participative Leadership Style On The Performance Of COYA Senior Managers In Kenya". Researchjournali's Journal of Management. 4 (5), 1-12.

Marwansyah. (2014). Manajemen Sumber Daya Manusia. Cetakan Ketiga. Alfabeta: Bandung.

Mulyana, Mumuh. (2010). Manajemen Sumber Daya Manusia (SDM) Ritel DalamRangka Meningkatkan Perusahaan. Jurnal Ilmiah Ranggagading. 10 (2), 164-170.

Mustofa, Bahrul Ullum. (2016). "Pengaruh Kompetensi, Gaya Kepemimpinan Partisipatif Dan Budaya Organisasi Terhadap Kinerja Karyawan PT Surya Segara Surabaya”. Jurnal Ilmu Manajemen. 4 (4), 1-6.

Partiningsih, Selly. (2014). “Pengaruh Gaya Kepemimpinan Partisipatif Terhadap Kinerja Pegawai Pada Rumah Sakit Umum Daerah Abdul Wahab Sjahrane Kota Samarinda". Ejournal Ilmu Pemerintahan. 2 (1), 1787-1801.

Robbins SP, at al.(2006). Perilaku Organisasi ed 12, Jakarta: Salemba Empat Hal283.

Samsudin, Sadili. (2006). Manajemen Sumber Daya Manusia. Bandung: Pustaka Setia.

Sedarmayanti. (2009)Sumber Daya Manusia dan Produktivitas Kerja. Bandung: CV Mandar Maju.

Sudarmanto. (2009). Kinerja dan Pengembangan Kompetensi SDM: Teori, Dimensi Pengukuran dan Implementasi Dalam Organisasi. Yogyakarta: Pustaka Pelajar.

Sugandi, Suprayogi. (2011). Administrasi Publik, Edisi Pertama, Cetakan Pertama. Yogyakarta: Graha Ilmu.

Sugiyono. (2013). Statistika Untuk Penelitian. Bandung: Alfabeta.

Suherman. (2003). Evaluasi Pembelajaran Matematika. Bandung: JICA FPMIPA UPI.

Sulaiman, Mukhlis Yunus, Amri. (2014). "Pengaruh Gaya Kepemimpinan Dan Gaya Komunikasi Terhadap Kinerja Pegawai Serta Dampaknya Pada Kinerja

Sekretariat Daerah Kabupaten Pidie Jaya". Jurnal Manajemen. 3 (2). 
Sunyoto, Danang. (2015). Penelitian Sumber Daya Manusia. Jakarta: CapsPublishing. Supardi, M.d. (2006). Metodologi Penelitian. Mataram: Yayasan Cerdas.

Suparno. (2012). "Pengaruh Gaya Kepemimpinan Autocrative dan ParticipativeTerhadap Prestasi Kerja Karyawan Pada Politeknik Tri Mitra KaryaMandiri”.Jurnal Ilmiah Ekonomi Akun. 2 (3).

Sutrisno Edy Dr, M.Si. (2010). Manajemen Sumber Daya Manusia. Jakarta: Kencana Predana Media Grup

Syaiful Arifin, Basworo Dibyo. (2016). “Analisis Pengaruh Gaya Kepemimpinan Partisipatif, Motivasi Dan Disiplin Kerja Terhadap Kinerja Pegawai Pada PT Bank Bukopin Tbk. Cabang Klaten". Skripsi. Universitas Muhammadiyah Surakarta.

Tampi, Bryan Johannes. (2012). "Pengaruh Gaya Kepemimpinan Dan MotivasiTerhadap Kinerja Karyawan Pada PT Bank Negara Indonesia”.JournalActa Diurna. 3 (4).

Tampubolon, Biatna Dulbert (2014). "Analisis Faktor Gaya Kepemimpinan DanFaktor Etos Kerja Terhadap Kinerja Pegawai Pada Organisasi Yang TelahMenerapkan SNI". Jurnal Standardisasi. 9 (3), 106-115.

Tatbighi, Ali. (2008). "Examining the Effect of Group Work ing in Participative Management on Employee's Performance of Public Organizations in Borojerd City". MA thesis, Borojerd branch, Islamic Azad University. 6 (26), 1-251.

Thoha, Miftah. (2010). Kepemimpinan Dalam Manajemen. Jakarta: PT Raja Grafindo Persada Hal 49-50.

Veithzal Rival Zainal, dkk. (2014). "Manajemen Kinerja Untuk Perusahaan dan Organisasi (Cara Tepat dan Mudah Menilai Kinerja)". Cetakan Pertama. BPFE: Yogyakarta.

Xu Huang, Joyce Iun, Aili Liu, dkk. (2010). "Does Participative Leadership Enhance Work Performance By Inducing Empowerment Or Trust? The Differential Effects On Managerial And Non-Managerial Subordinates". Journal of Organizational Behavior.31, 122-143. 